\title{
Integration of Volcanic Eruption Disaster Education with Physics Learning Process to Improve Students' Disaster Preparedness in Magelang Regency
}

\author{
Mufida M Jannah ${ }^{1, *}$, Jumadi ${ }^{2}$,Herawati ${ }^{1}$ \\ ${ }^{1}$ Master of Physics Education, Faculty of Mathematics and Natural Sciences, Yogyakarta State University, \\ Indonesia \\ ${ }^{2}$ Department of Natural Science Education, Faculty of Mathematics and Natural Sciences, Yogyakarta State \\ University, Indonesia \\ *Corresponding author. Email: mufidamiftahul.2019@student.uny.ac.id
}

\begin{abstract}
This research was aimed to study the integration of volcanic eruption disaster education with physics learning process to improve senior high school students' preparedness for volcanic eruption in Magelang Regency. This research used descriptive qualitative method, consisted of two stages: survey using questionnaire and interview. The results of this research showed that students' volcanic eruption preparedness was still low. Students were still having minimum knowledge about volcanic eruption disaster preparedness because there was no knowledge and simulation about volcanic eruption preparedness at school. Integration of disaster education into the school curriculum was one of the strategies that can be done to deal with disaster through education.
\end{abstract}

Keywords: Disaster integrated learning, Physics, Preparedness, Volcanic eruption

\section{INTRODUCTION}

Based on its geographical location, Indonesia is located between the boundaries point of the three major tectonic plates of the Earth. Namely the Eurasian Plate, the Pacific Plate, and the IndoAustralian Plate. This geographical location is the main causes of natural disasters in Indonesia [1]. Table 1 presents the facts of natural disasters that occurred in Indonesia from 2019 until 2020.

Indonesia has many volcanoes. Some of them are still active today. One of them is Mount Merapi, which located along the border of Central Java and Yogyakarta. Mount Merapi has erupted more than 80 times [2]. The largest eruption occurred in 2010 [3]. In 2019 until 2020 there were four volcanic eruptions recorded based on data from the National Disaster Management Agency.

Common hazards that occur due to the eruption of Mount Merapi include the incandescent lava, volcanic ashes, and cold lava. The volcanic ashes and cold lava due to the eruption of Mount Merapi have hit the surrounding areas. Magelang Regency was one of the areas affected by the eruption of Mount Merapi [3]. Figure 1 shows the illustration of Mount Merapi Volcanic Eruption. Figure 2 shows the volcanic ashes after Mount Merapi eruption on June $21^{\text {st }}, 2020$. Figure 3 shows the post eruption lahars [2] and Figure 4 shows the impact of lahars [2].

Table 1. Disaster Incidence Data in Indonesia from 2019 until 2020

\begin{tabular}{|l|c|c|}
\hline Disaster T ype & $\begin{array}{l}\text { umber of } \\
\text { Events }\end{array}$ & $\begin{array}{l}\text { T he injured } \\
\text { victims }\end{array}$ \\
\hline Flood & 390 & 1047 \\
\hline Landslide & 356 & 81 \\
\hline $\begin{array}{l}\text { Floods and } \\
\text { Landslides }\end{array}$ & 5 & 1 \\
\hline Abrasion & 8 & 4 \\
\hline Whirlwind & 575 & 124 \\
\hline Forest Fires & 55 & 0 \\
\hline Earthquakes & 13 & 147 \\
\hline $\begin{array}{l}\text { Volcanic } \\
\text { Eruption }\end{array}$ & 4 & 0 \\
\hline
\end{tabular}




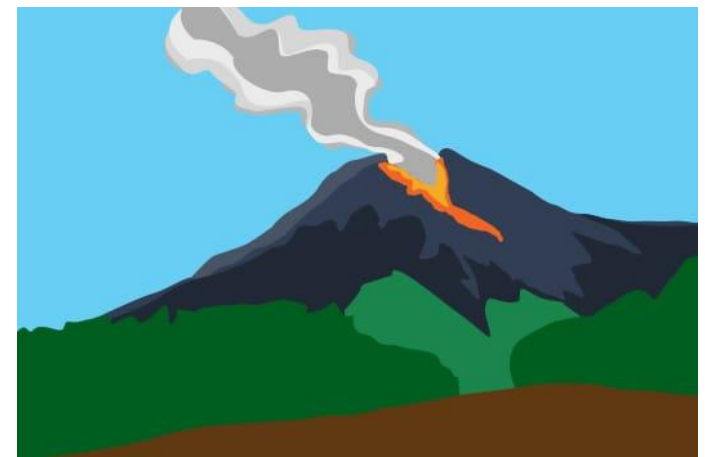

Figure 1. Volcanic Eruption

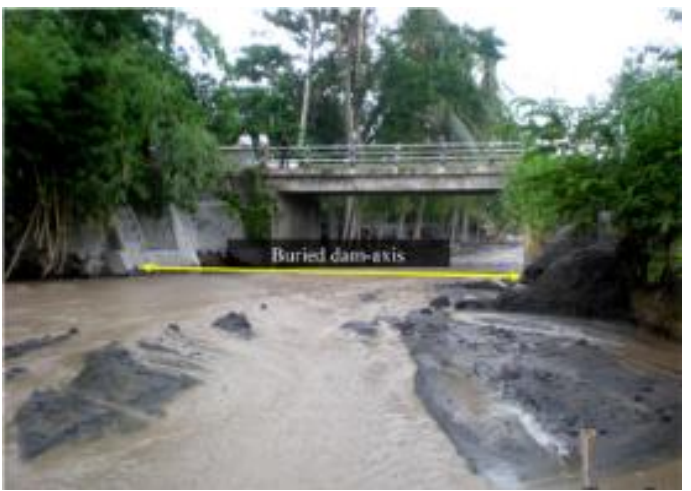

Figure 3. Lahars After Eruption

Public participation is needed to deal with the Merapi volcanic eruption. However, public awareness about disaster was still minimum [4]. In the society, school-aged children are most vulnerable to disasters, so preparations for disasters must be made for them through education. School-aged children have the potential to be an effective agent to communicate disaster mitigation, preparedness, and information to their parents [5].

Knowledge and preparedness for natural disasters can be implemented by various ways. One of them, by designing Standard Operating Procedures (SOP) at schools [6]. Schools played important roles in providing the knowledge about disasters including disaster prevention, disaster management methods, and post-disaster recovery [7]. Disaster education at schools was aimed to increase students' awareness of the impacts of the disasters and encourage students' preparedness for natural disasters [5]. In addition, it may increase students' knowledge about disasters, including prevention, response, assistance, and preparedness planning to provide an overview and how to handle disasters in an appropriate way [7].

Disaster education strategies in schools can be integrated into subjects related to natural disasters.

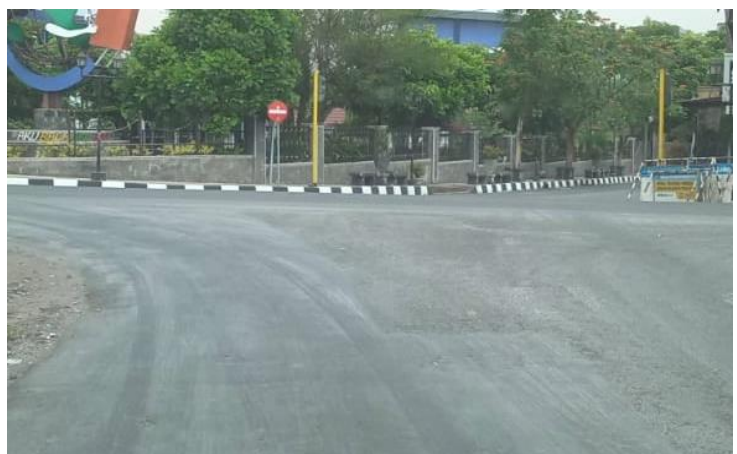

Figure 2. Volcanic Ashes After Eruption

(Image taken on June $21^{\text {st }}$, 2020)

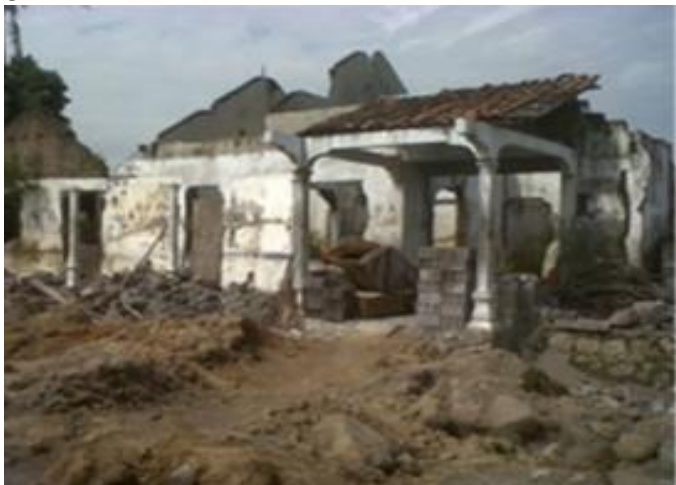

Figure 4. Impact of Lahars

For elementary and junior high school students, it can be integrated into Natural Science subjects. Meanwhile, for high school students it can be integrated into physics subjects [8]. This can be done by adding disaster simulations in the learning process [9], using pictures and worksheets [8], videos, posters, experiments, demonstrations [10] and teaching materials [11]. Knowledge of natural disasters needs to be taught to the students from an early stage, so students can be better to prepared for disasters [12].

Considering that several schools in Magelang were in the areas affected by the eruption of Mount Merapi, it is necessary to integrate the volcanic disaster education. One of them is in physics subject. The purpose of this research was to study the integration of volcanic eruption disaster education in physics learning as an effort to improve students' preparedness in high schools in Magelang Regency.

\section{RESEARCH METHOD}

The method of this research was descriptive qualitative, consisted of two stages: survey using questionnaire and interview. The subjects of this research consisted of 10 students who were attended 
school in prone areas of volcanic eruptions in Magelang Regency. The instruments used were interview guideline and questionnaire sheet. The interview guideline consisted of six questions, shows in Table 2. While the questionnaire sheet instrument consisted of eight questions covering two aspects, namely education and preparedness aspects, shows in Table 3.

The preparedness interview data analysis was conducted in a descriptive qualitative manner. The questionnaire used a Likert scale by giving the highest score, 5 for strongly agreeing answer and the lowest score, 1 for strongly disagree answer. Equation (1) used to get the percentage of each aspect.

$P_{n}=\frac{f}{N} \times 100 \%$

Table 2. Questions of Interview
$P_{n}$ is the percentage of volcanic eruption disaster preparedness, $f$ is the total score for each indicator, and $N$ is the maximum score for each indicator?

\section{RESULT AND DISCUSSION}

Integration of disaster education in schools was very important to provide students' knowledge in dealing with disaster, especially volcanic eruption. The students' knowledge may increase the students' preparedness. Students were expected to be able to convey their knowledge to their families at home [8].

\subsection{Survey Stage using a Questionnaire}

The results of the questionnaire about the integration of disaster education and preparedness in schools can be seen in the Figure 5.

\begin{tabular}{|c|l|}
\hline umber & uestion \\
\hline 1. & Have volcanic eruption disaster preparedness been implemented in the schools? \\
\hline 2. & How is the implementation of preparedness in schools? \\
\hline 3. & Have you ever conducted a volcanic eruption disaster preparedness simulation? \\
\hline 4. & Do you know where the evacuation route near your school located? \\
\hline 5. & How do you prepare yourself if one day you deal with the volcanic eruption disaster? \\
\hline 6. & Do you know what should you do after the volcanic eruption disaster occurred? \\
\hline
\end{tabular}

Table 3. Aspects and question on the survey

\begin{tabular}{|c|c|c|}
\hline Aspect & umber & uestion \\
\hline \multirow[t]{3}{*}{ Education } & 1. & $\begin{array}{l}\text { Has the school made it a practice to insert information and preparedness to deal } \\
\text { volcanic eruptions through several subjects, especially physics subjects for all } \\
\text { students? }\end{array}$ \\
\hline & 2. & Has your school ever held any training in how to deal with a volcanic eruption? \\
\hline & 3. & $\begin{array}{l}\text { Has your school have a special sign for early warning purposes in case of a } \\
\text { volcanic eruption? }\end{array}$ \\
\hline \multirow[t]{5}{*}{ Preparedness } & 4. & $\begin{array}{l}\text { Has the school been disseminating information on procedures for dealing with } \\
\text { volcanic eruptions to the parents of students and their families by utilizing the school } \\
\text { committee? }\end{array}$ \\
\hline & 5. & $\begin{array}{l}\text { Have you ever been trying to find a lot of information about the volcano eruption and } \\
\text { its effects from various sources? }\end{array}$ \\
\hline & 6. & $\begin{array}{l}\text { Having the experience of Merapi eruption, do you know what preparations must be } \\
\text { prepared in case a volcanic eruption? }\end{array}$ \\
\hline & 7. & Do you know the appropriate way to take cover in the event of a volcanic eruption? \\
\hline & 8. & Do you know any signs of a volcano eruption? \\
\hline
\end{tabular}




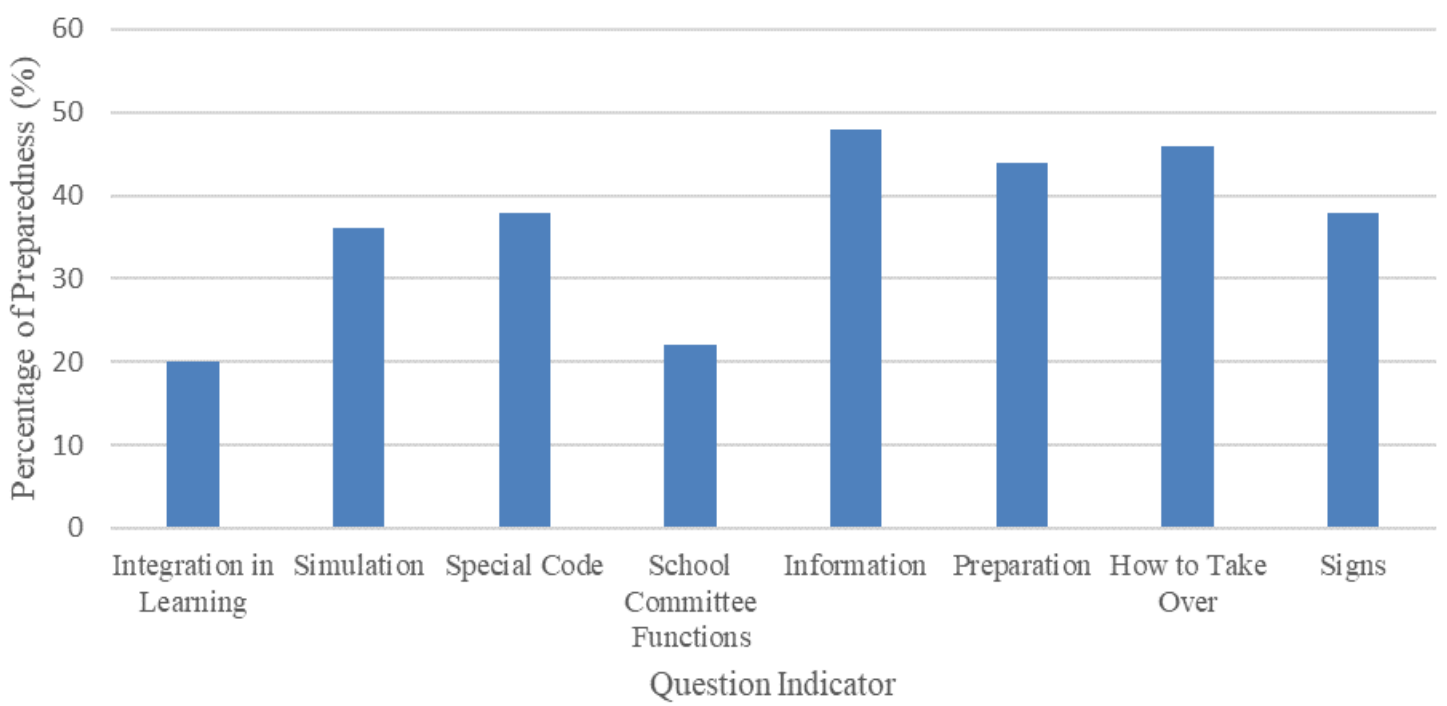

Figure 5. Percentage of volcano eruption disaster preparedness for High School students in Magelang regency

The students' preparedness for volcanic eruption was still low. This was shown by the percentage of the results which can be seen in Figure 5. The first question with the indicator of integration in learning get the lowest percentage, $(20 \%)$. This shows that the integration of disaster education still has not been done in the schools. The fifth question, the information about the volcano eruption and its impact obtained the highest percentage, (48\%). Overall, the percentage obtained was still below $50 \%$.

The questionnaire given to students consisted of two aspects. The first aspect was about the education in schools, consisted of three questions. The most chosen answer by the students was that the school never inserted any information and preparedness to deal with the volcanic eruption through several subjects. The school has never conducted the procedures for dealing volcanic eruption and does not have a special code or sign for early warning purpose in the event of a volcanic eruption. From the students' answers, the three questions resulted in a low percentage.

The second aspect was about the preparedness of students which consisted of five questions. Overall, students still have a minimum knowledge about volcanic eruption preparedness. Some students have been looking for information about volcanic eruption and its impacts, but there are no. more than three sources, hence disaster education needs to be included in the learning process in schools prone to volcanic eruption.

\subsection{Interview Stage}

After survey, the next stage was an interview about the preparedness for the volcano eruption. The results of the interview showed in Table 4.

Overall, disaster preparedness, especially volcanic eruptions, has not been implemented optimally in their schools. Disaster simulations and socialization about evacuation route or safe points near the schools have not been put into practices. Some students know how to prepare themselves if one day there was a volcanic eruption and what to do after a volcanic eruption occurs. The activities that conducted by students in preparing themselves in case of a volcanic eruption and after a volcanic eruption are activities which conducted based on their own experiences. Students do not know whether the activities they are doing are right or wrong, so they need further explanation from parties who knew better, as an example from teacher. 
Table 4. The Results of Preparedness Interview

\begin{tabular}{|c|l|}
\hline $\begin{array}{c}\text { uestion } \\
\text { umber }\end{array}$ & Answer \\
\hline 1. & $\begin{array}{l}\text { All students said that volcanic eruption disaster preparedness had not been implemented in the } \\
\text { schools. }\end{array}$ \\
\hline 2. & $\begin{array}{l}\text { Overall, students said that the school had not implemented disaster preparedness activities. One } \\
\text { student said that the school had prepared an evacuation route sign at a certain point. }\end{array}$ \\
\hline 3. & $\begin{array}{l}\text { All students said that they had never conducted any volcanic eruption disaster preparedness } \\
\text { simulation. }\end{array}$ \\
\hline 4. & $\begin{array}{l}\text { Seven students did not know where the evacuation route to the safe point located near to their } \\
\text { school. }\end{array}$ \\
\hline 5. & $\begin{array}{l}\text { Eight from ten students have prepared themselves if one day they deal with the volcanic eruption } \\
\text { disaster. }\end{array}$ \\
\hline 6. & $\begin{array}{l}\text { Five from ten students know what they must do after volcanic eruption disaster occurred such as } \\
\text { not returning home before instructions were given, monitoring information from related authorities, } \\
\text { wearing masks, avoiding cold lava hot spots, cleaning the environment, and doing community } \\
\text { service to repair public facilities. }\end{array}$ \\
\hline
\end{tabular}

Integration of disaster education can be included in the school curriculum, considering that Indonesia is a disaster-prone area. Teachers are expected to have an effort to provide knowledge about natural disasters to the students [13]. Efforts from teachers to provide knowledge about volcanic eruptions can be done by providing information to students about the latest issues and facts about volcanic eruption. Disaster signs, disaster risks, symptoms, causes, and ways to prevent victims from disasters to increase students' preparedness for volcanic eruptions and simulations related to volcanic eruptions can also be conducted [14].

Magelang Regency, one of the areas affected by volcanic eruption disaster, requires education in schools which integrated with volcanic eruptions. One of them is through integrated physics learning with volcanic eruptions. The materials and learning models used must be suitable and relevant with the disaster topic. Suitable physics materials are work and energy, impulse and momentum [15], temperature and heat, vector or thermodynamic analysis [16]. According to the results of a latest survey about students' preparedness, it shows that it is very necessary to implement the teaching and learning activities using an integrated learning model to improve disaster preparedness and students' scientific knowledge [17]. The design of natural science learning models integrated disasters education is practical and effective to be used in learning process [18]. In addition, the integration of learning models based on local wisdom is also suitable, because it may be adapted to the requirements of disaster-prone schools [19].
Based on the results of surveys and interviews that have been conducted, there is a need for integration of volcanic eruption disaster education in physics. This can be done by considering materials that relevant to the topic of volcanic eruptions.

\section{CONCLUSION}

Integration of volcanic eruption disaster preparedness has not been implemented optimally. Therefore, it is necessary to integrate disaster education into the school curriculum as one of the strategies that can be done to deal the volcanic disasters through education in senior high school in Magelang Regency.

\section{REFERENCES}

[1] B. Setiawan, D.K. Innatesari, W.B. Sabtiawan, S. Sudarmin, The Development of Local Wisdom-Based Natural Science Module to Improve Science Literation of Students, Jurnal Pendidikan IPA Indonesia, 6(1) (2017) 49-54. DOI: https://doi.org/10.15294/jpii.v6i1.9595

[2] D.S. Hadmoko, E.D. Belizal, B.W. Mutaqin, G. A. Dipayana, M.A. Marfai, F. Lavigne, J. Sartohadi, S. Worosuprojo, C.C.A. Starheim, C. Gomez, Post-Eruptive Lahars at Kali Putih Following the 2010 Eruption of Merapi Volcano, Indonesia: Occurrences and Impacts, Natural Hazards 94 (2018) 419-444. DOI: https://doi.org/10.1007/s11069-018-3396-7

[3] Y.N. Maharani, S. Lee, S.J. Ki, Social Vulnerability at a Local Level Around the 
Merapi Volcano, International Journal of Disaster Risk Reduction 20 (2016) 63-77. DOI: http://dx.doi.org/10.1016/j.ijdrr.2016.10.012

[4] I.K. Setiawati, A. Rusilowati, Khumaedi, Pembuatan Buku Cerita IPA yang Mengintegrasikan Materi Kebencanaan Alam untuk Meningkatkan Literasi Membaca dan Pembentukan Karakter, Jurnal Pendidikan IPA Indonesia 2(2) (2013) 129-135. DOI: https://doi.org/10.15294/jpii.v2i2.2713

[5] H. J. Boon, P. J. Pagliano, Disaster Education in Australian Schools, Australian Journal of Environmental Education, 30(2) (2014) 187197. DOI: https://doi.org/10.1017/aee.2015.8

[6] M. Desfandi, Urgensi Kurikulum Pendidikan Kebencanaan Berbasis Kearifan Lokal di Indonesia, SOSIO DIDAKTIKA: Social Science Education Journal 1(2) (2014) 191-198. DOI: https://doi.org/10.15408/sd.v1i2.1261

[7] T.T. Zhu, Y.J. Zhang, An Investigation of Disaster Education in Elementary and Secondary Schools: Evidence from China, Natural Hazards 89 (2017) 1009-1029. DOI: https://doi.org/10.1007/s11069-017-3004-2

[8] Z. Septikasari, Y. Ayriza, Strategi Integrasi Pendidikan Kebencanaan dalam Optimalisasi Ketahanan Masyarakat Menghadapi Bencana Erupsi Gunung Merapi, Jurnal Ketahanan Nasional 24(1) (2018) 47-59. DOI: https://doi.org/10.22146/jkn.33142

[9] J.S. Chou, K.H. Yang, T.C. Ren, Ex-Post Evaluation of Preparedness Education in Disaster Prevention, Mitigation and Response, International Journal of Disaster Risk Reduction 12 (2015) 188-201. DOI: https://doi.org/10.1016/j.ijdrr.2015.01.002

[10] J.J. Wang, Study on the Context of SchoolBased Disaster Management, International Journal of Disaster Risk Reduction 19 (2016) 224-234.

DOI: https://doi.org/10.1016/j.ijdrr.2016.08.005

[11] P.T. Apronti, S. Osamu, K. Otsuki, G.K Berisavljevic, Education for Disaster Risk Reduction (DRR): Linking Theory with Practice in Ghana's Basic Schools, Sustainability 7(7) (2015) 9160-9186. DOI: https://doi.org/10.3390/su7079160

[12] B. Hidayat, K. Kuswono, Implementasi Model Pembelajaran Integrated pada Perkuliahan
Pendidikan Ilmu Sosial di FKIP UM Metro, Historia: Jurnal Program Studi Pendidikan Sejarah 2(2) (2014) 117-123. DOI: http://dx.doi.org/10.24127/hj.v2i2.325

[13] F. Ferawati, A. Rusilowati, Supriadi, Keefektifan Pembelajaran Bencana Alam Bervisi SETS Terintegrasi dalam IPA dengan Media Animasi dan Lembar Pertanyaan, Jurnal Pendidikan Fisika Indonesia 8(2) (2014) 184189.

DOI: https://doi.org/10.15294/jpfi.v8i2.2158

[14] L. Rahmawati, U.N. Labibah, H. Kuswanto, The implementation of android-based physics learning media integrated with landslide disaster education to improve critical thinking ability and disaster preparedness, in: Journal of Physics Conference Series, vol. 1440, IOP Publishing, Bristol, 2020, pp. 1-6. DOI: http://doi.org/10.1088/17426596/1440/1/012042

[15] R. Alkadri, Festiyed, Asrizal, Meta-Analisis Bahan Ajar Terintegrasi Materi Mitigasi Bencana Alam Terhadap Kompetensi Peserta Didik, Pillar of Physics Education 12(4) (2019) 857-864.

DOI: http://dx.doi.org/10.24036/7909171074

[16] M. Arif, D. Syaflita, Analysis of Physics Learning Matter Integrated Disaster in West Sumatera, Jurnal Geliga Sains Jurnal Pendidikan Fisika 6(2) (2019) 114-119. DOI: http://dx.doi.org/10.31258/jgs.6.2.114-119

[17] U.N. Labibah, H. Kuswanto, Susiyanti, Integrated landslide disaster education in physics subject viewed from high school students preparedness in Kulon Progo, Yogyakarta, in: Journal of Physics: Conference Series, vol. 1440, IOP Publishing, Bristol, 2020, pp. $1-5$. DOI: http://doi.org/10.1088/17426596/1440/1/012026

[18] N. Wedyawati, Y. Lisa, S. Selimayati, Pengaruh Model Pembelajaran IPA Terintegrasi Mitigasi Bencana terhadap Hasil Belajar, Jurnal Edukasi 15(2) 2617) 261-273. DOI: http://dx.doi.org/10.31571/edukasi.v15i2.636

[19] A. Pamungkas, B. Subali, S. Linuwih, Implementasi Model Pembelajaran IPA Berbasis Kearifan Lokal untuk Meningkatkan Kreativitas dan Hasil Belajar Siswa, Jurnal Inovasi Pendidikan IPA 3(2) (2017) 118-127. DOI: http://dx.doi.org/10.21831/jipi.v3i2.14562 